\title{
Factors influencing tenure choice in European countries
}

\author{
Monika Bazyl \\ Department of Applied Econometrics \\ Warsaw School of Economics \\ monika.bazyl@doktorant.sgh.waw.pl
}

April, 2009

\begin{abstract}
Homeownership rates are very different across European countries. They range from below $50 \%$ in Germany to over $80 \%$ in Greece, Spain or Ireland. However the differences lie not only in the overall homeownership rates but also in its structure, and this is the focus of this paper. Its aim is to study the impact of microeconomic factors on household's tenure choice, using a cross-country comparative approach. Logit models are constructed for each country using data for year 2000 from the Consortium of Household Panels for European Socio-Economic Research micro-database. The models show that marriage is a significant determinant of the decision to move to homeownership in all analysed countries, while cohabitating households are more likely to rent, except for Denmark. Nationality, income and age proved to be significant explanatory variables in several countries, while staying insignificant in others.
\end{abstract}

Keywords: tenure choice, homeownership, housing

JEL Classification: D10, R20

\section{Acknowledgements}

The present research was (co-)funded by the European Commission under the 6th Framework Programme's Research Infrastructures Action (Trans-national Access contract RITA 026040) hosted by IRISS-C/I at CEPS/INSTEAD, Differdange (Luxembourg). 


\section{Introduction}

There is no such thing as one European housing market yet. Housing conditions and the way housing markets work are very different in each European country. One of the basic differences is homeownership rate, which ranges from below 50\% in Germany to over $80 \%$ in Greece, Spain or Ireland. This is a result mainly of different housing policies applied over past decades by each country. Policy makers try to make access to a dwelling easier either by supporting rental housing (e.g. by providing social rented housing or giving tax reliefs for investment in rental housing) or by supporting the purchase of an own house (e.g. providing interest tax reliefs in income taxes) (Barcelo, 2006). However, does that mean that if a common European housing policy was applied a cohesion of housing markets would be gradually achieved? This paper is a step towards answering this question. It looks at socio-demographic structure of homeowners and renters in European countries and then evaluates the impact of microeconomic factors (such as age, country of citizenship of the breadwinner, marital status, household income) on household's tenure choice. Analysis of housing market from microperspective is not new. There is a wide literature devoted particularly to determinants of housing tenure choice. Apart from socio-demographic also other categories of factors are usually considered: economic (the cost of ownership versus rent prices, tax considerations, wealth and borrowing constraints, risk of rent or house price fluctuations, income uncertainty, transacion costs), psychological or spacial factors. This paper concentrates on socio-demographic characteristics of households as the factors of tenure choice.

\section{Homeownership versus renting}

Homeownership is in many countries encouraged and financially supported by the state. Favourable tax system for homeowners, special support programs for first time buyers as well as state support to repay mortgage for unemployed in the wake of economic crisis (e.g. USA, Poland) clearly shows that homeownership is treated as a better tenure choice for citizens in these countries. Arimah (1997) mentiones several reasons, why homeownership is favoured by state policies. The main are that it is believed to foster economic growth and it contributes to financial stability and well-being of a family. Therefore, homeownership began to be a life-time goal for many households. According to a survey conducted by BenShahar (2007) psychological factors are often more important in explaining tenure choice than economic factors. For most of the respondents, homeownership was associated with independence, better psychological feeling and they perceived homeownership as a higher social status than that of a renter. What is more, many agreed that they felt that society, 
in general, expected a person to own a dwelling at some point of lifetime. Majority (85\%) of respondents agreed with the statement that a purchase of a house was superior to rent because the buyer had an asset after repaying mortgage, while renting left the renter with nothing. This 'common wisdom' is not always correct from the financial point of view. Hennessey (2001) points out that although two-thirds of households in North America own a house and the rest treats homeownership as their life goal it is not always a wise choice to purchase a house. High mortgage interest rates and high downpayment requirements might prove that the opportunity cost of owning is too high. Instead of investing in a home purchase a household could simply rent and use their money more wisely by investing in other financial assets. But again the author acknowledges, that emotional and psychological factors make people decide to become homeowners even if in the given economic conditions this decision is worse from the financial point of view.

There are countries however, where homeownership is not worshiped so much. Figure 1 shows percentage of homeowners and renters in 16 European countries ${ }^{1}$. Percentage figures were calculated using CHER database, whis is described in detail in section 4.

Figure 1: Homeownership rates by country (source: CHER 2000)

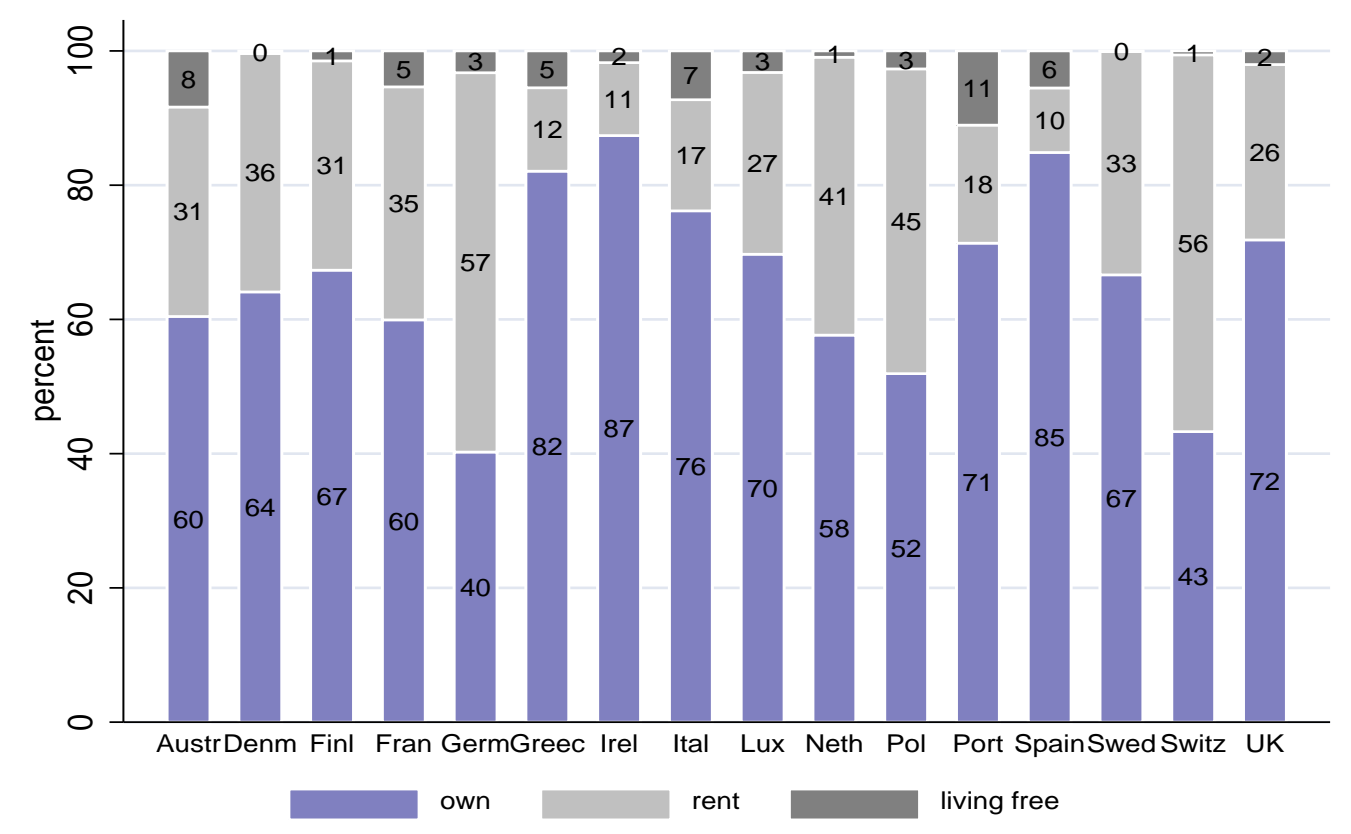

In Germany and Switzerland the share of households which rent their home is larger than

\footnotetext{
${ }^{1}$ Due to missing data or absence of certain variables in some countries the comparison will cover each time a different subsample of countries.
} 
the share of homeowners. In year 2000 in Germany $57 \%$ of households who took part in German Socio-Economic Panel were renting their homes and in Switzerland 56\% of households who took part in Swiss Household Panel were renting their homes. In Germany the taxation policy favours investment in rental market rather than homeownership (Earley, 2004). Poland, which represents here post-transition housing ${ }^{2}$, also has a large percentage of renters $-45 \%$. However, due to a new policy of selling off community owned properties to tenants for very low prices this percentage will be much lower in ten years time. As Earley (2004) notices in United Kingdom in 1979 owner occupation level was just 55\% but after introducing a policy of selling off social rented housing to tenants the homeownership rate increased very quickly.

When talking about rental market one has to bear in mind that there are different types of landlords prevalent in each country. For example Greek rental market, though small is almost entirely private (96\%, Figure 2). Similar cases are Spain and Portugal. In countries like Austria, Denmark, Finland, France or United Kingdom rental market is much bigger but almost in half it is provided by public landlord. In case of Luxembourg and Netherlands actually all rental market is provided by public landlord (87\%-89\%). Definition of public landlord is also not unique across countries. It covers municipal authorities as well as nonfor-profit agencies and other bodies. The substantial size of the public rental provides an alternative for private rental market as well as helps to keep private rental market prices low.

Ownership status is far from being unique across countries as well. Fisher and Jaffe (2003), who carry out a comparative study on determinants of international homeownership rates, acknowledge that the definition of homeownership is different in each country as there are different sets of rights associated with ownership in each country. Therefore, a binary variable classifying households into just two categories 'owners' or 'renters' is a simplification of housing tenure choice, but in our study a simplification is unavoidable in order to carry out a feasible analysis.

\section{Previous studies on tenure choice}

There is a wide literature on impact of different factors on housing tenure choice. It can be classified depending on which subset of explanatory variables it concentrates on: socio-demographic like marriage, age, children; economic like the cost of ownership versus rent prices (Arimah, 1997; Skaburskis, 1999), tax considerations (Bourassa and Yin, 2006),

\footnotetext{
${ }^{2}$ Data for Hungary were also available, but they covered the period till 1997.
} 
Figure 2: Types of landlords on rental market by country (source: CHER 2000)

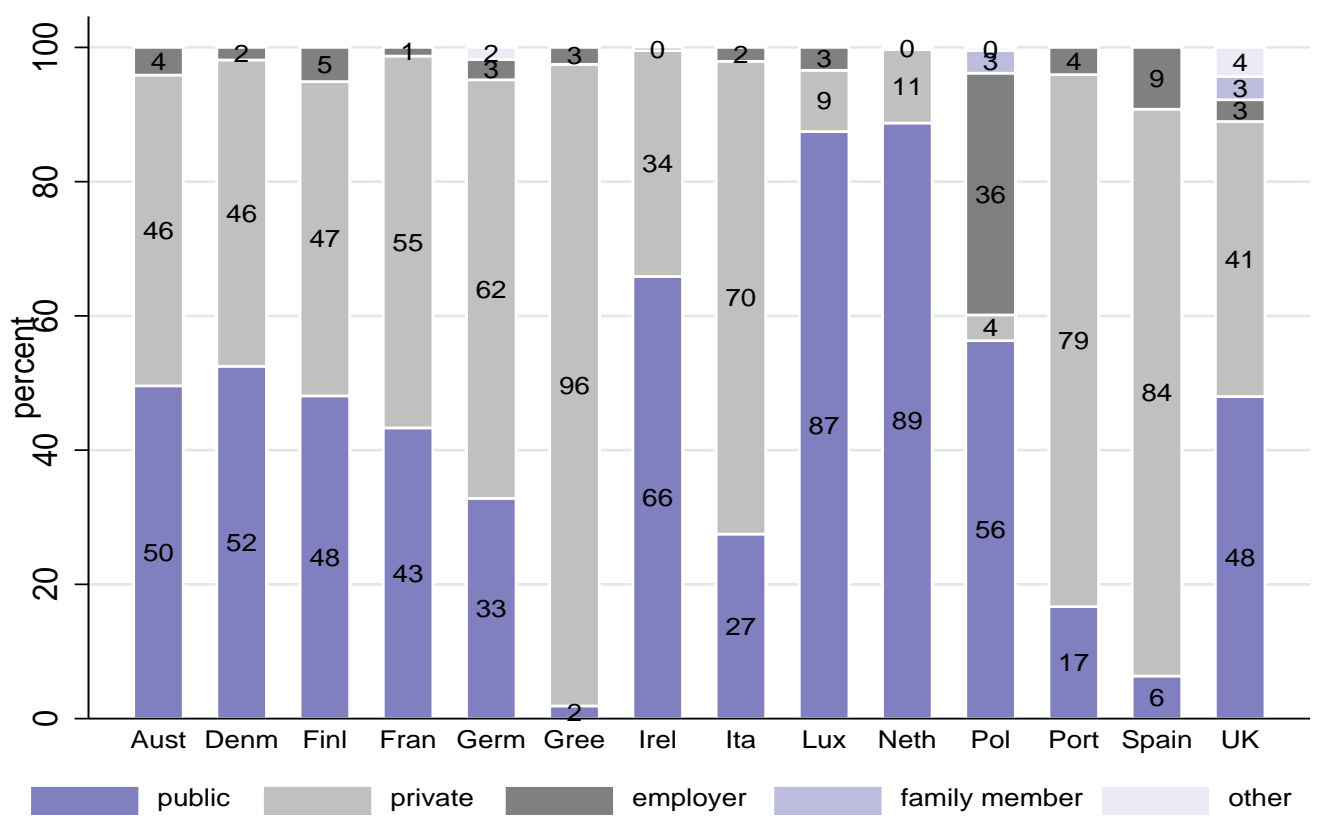

wealth and borrowing constraints (Bourassa, 2000), risk of rent or house price fluctuations, income uncertainty, transacion costs, housing allowances (Chen and Ost, 2005); psychological (Ben-Shahar, 2007) or spacial (Iwarere and Williams, 1991; Gabriel and Painter, 2008). Andrew and Meen(2003) and Andrew (2004) concentrated their tenure choice research on young households, as they are treated as the core of housing market. Their tenure decision was usually jointly analysed with the decision whether to form a new household.

Although microeconomic studies devoted to tenure choice are numerous most of them are concentrated on one single country, few are trying to explain differences between two countries. For example Bourassa and Yin (2006) compared impact of different subsidy policies on tenure choice in United States and Australia. Clark, Deurloo and Dieleman (1997) carried out a cross-national comparison of tenure choice between Germany and United States, also to unerstand the impact of different government policies. Comparative literature across several countries based on microecoomic data is young, which is simply connected with access to data. It was not easy to carry out comparative research untill special cross-country surveys have been made available for researchers to access (like European Household Panel Survey) and databases for comparative studies have been constructed (e.g. micro-database: Consortium of Household Panels for European Socio-Economic Research). 


\section{Data and model specification}

Analysis presented in this paper is based on CHER micro database offering comparable data for Europen countries. CHER (Consortium of Household Panels for European SocioEconomic Research) contains information from 7 National Panels (GSOEP for Germany; BHPS for the United Kingdom; PSELL for Luxembourg; HBS for Poland; HHS for Hungary; PSBH for Belgium, SHP for Switzerland and PSID for USA) and for other countries from ECHP dataset. Alltogether data for 18 European countries are included in the databse covering the economic situation, family and household composition, housing and living conditions and individual wellbeing (Birch and others, 2003). Cross-sectional analysis in this paper is based mainly on data for year 2000 (data for 16 countries available).

Comparative study is carried out by constructing a tenure choice model and then estimating its coefficients for each country separately. Thus we can see in which country model fits the data better and we can compare the significance of the coefficients and the magnitude of the impact of explanatory variables on the odds of homeownership. In most of the previous studies tenure choice is modeled as a logit regression, though probit model could also be used. Here housing tenure choice is modeled as logit regression:

$$
\ln \frac{P(O W N=1 \mid x)}{1-P(O W N=1 \mid x)}=\sum \beta_{k} x_{k}
$$

Where $x_{k}$ are the explanatory variables described below in this section, $\beta_{k}$ are the coefficients to be estimated and $P(O W N=1 \mid x)$ is the probability of homeownership for a given value of $x$. The logit model assumes that the probability of homeownership is a cumulative logistic function:

$$
P(O W N=1 \mid x)=\frac{1}{1+e^{-\sum \beta_{k} x_{k}}}
$$

Tenure choice is represented by a binary variable, taking value 1 for homeowners and 0 for tenants. We do not distinguish between private and social rental accommodation, because in some countries a particular mode of tenure choice almost does no exist, which does not allow to get reliable estimates for these countries and makes it difficult to carry out a cross-national comparison. A strategy of imposing one unique model on each country separately allows to compare significance of particular explanatory variables across all countries. This may be treated as a preceding step to constructing the best fitting model for each country, which would require a deep knowledge of each country in order to account for its specific features. 
The following explanatory variables were included in the model:

Figure 3: Homeownership rates by country and age (source: CHER 2000)

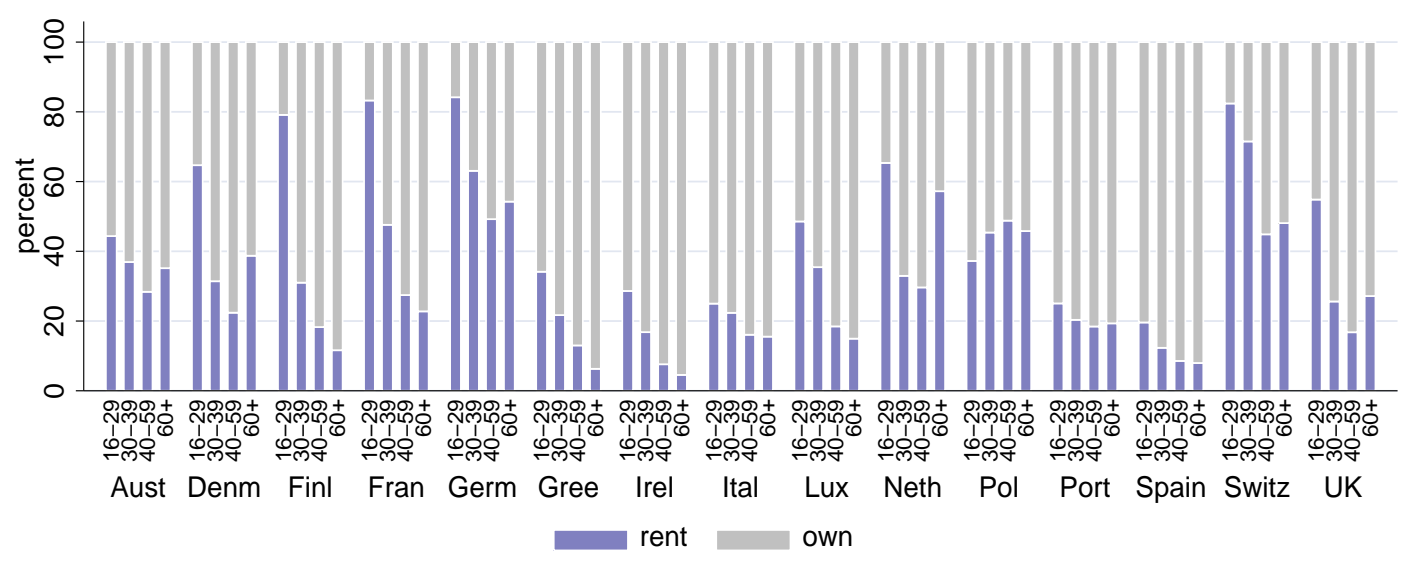

- Age of the household breadwinner (three dummy variables for age groups 30-39, 40-59 and 60 plus, where the youngest group 16-29 is the reference category). As Figure 3 shows, ownership rate is the lowest for households, where breadwinner is aged 16-29. For example in Germany and France, only 16\%-17\% of households in this age group are homeowners. The older the household breadwinner the higher probability that the household owns a home. However, in countries like Netherlands, Austria, Denmark, Germany and United Kingdon this trend is reversed in case of the oldest households $60+$. It is especially striking that in Netherlands the share of renters among the oldest households $60+$ rises to almost $60 \%$ compared to households aged $40-59$, where the share of renters is just about $30 \%$.

- Marital status as one dummy variable: married $=1$ where else $=0$. For a number of countries more detailed data are available, therefore for these countries a second model is constructed where two dummy variables are included in order to distinct between three types of huoseholds: marriage married1, parnership cohab or single (reference category).

Marriage is expected to be an incentive to buy a house. Partnership status might give less incentive to buy a house than marriage but still more than in case of a single person. However this depends on the level of acceptence of partnership status compared to marriage in each country. In countries like Denmark, where there is the largest share of households which are partnerships 17\% (Figure 4), there might be no difference between marriages and partnership status. In countries where partnerships constitute less than 5\% of households (like Ireland, Greece, Italy, Portugal or Spain) they might be much less inclined to buy a house than even single people. 
Figure 4: Share of marriages, partnerships and single people among all households (source: CHER 2000)

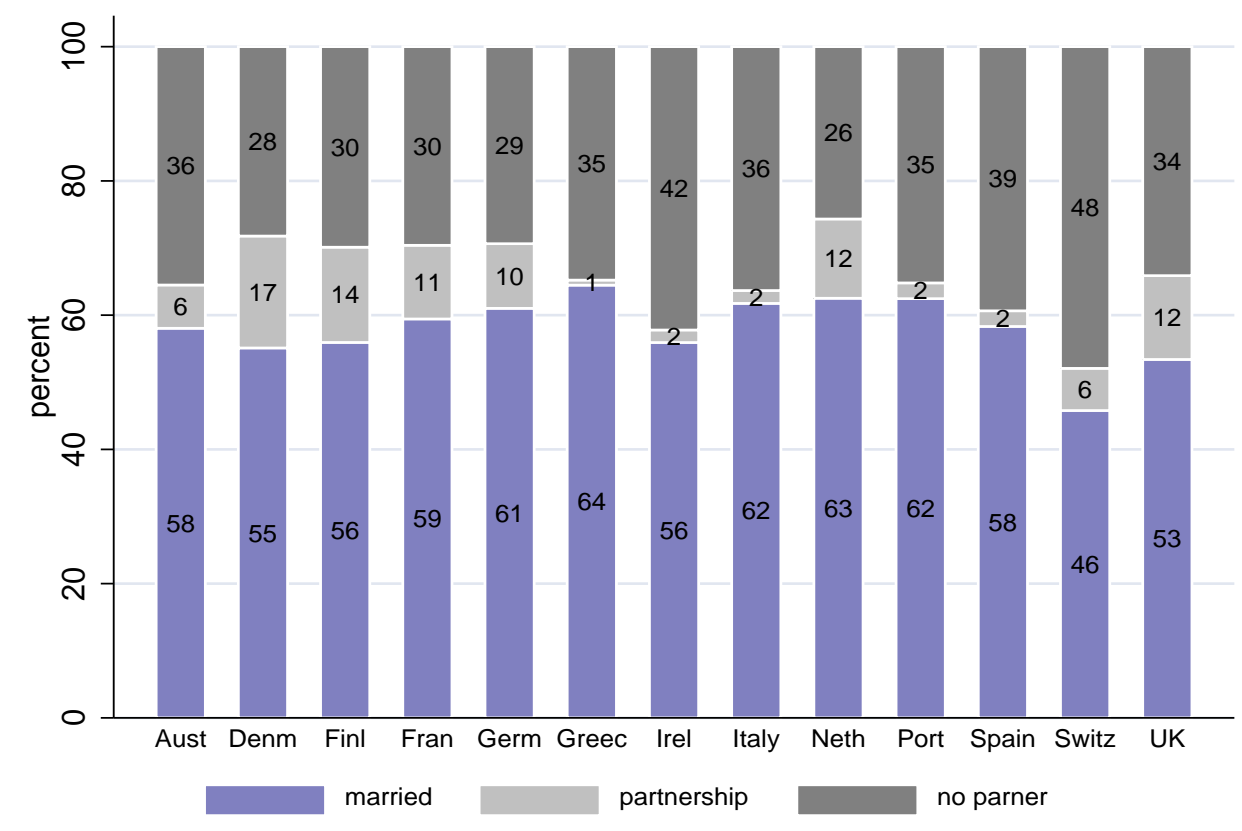

- Country of citizenship (national=1 not a national=0).

Nationality should either be not significant in case of tenure choice or have positive sign, as not-nationals tend rather to rent then own depending on their expected lenght of stay in the country. Figure 5 shows that in Denmark, Greece and Portugal the share of homeowners is similar for national and not nationals. In other countries share of homeowners is much bigger among nationals. The biggest discrepancies seem to be in Austria and Luxembourg.

- Urban/rural indicator (urban=1 rural=0).

Rental market is usually more common in urban area. In United Kingdom or Luxembourg the difference is rather small between urban and rural area in terms of homeownership rate. However in Poland the difference is substantial. In urban area only $26 \%$ of households are owners, while in rural area $87 \%$ of households are owners.

- Income (lninc - logarithm of yearly net disposable income of a household).

Higher income is expected to increase the probability of owning.

- PrevRoomsPerPers - Number of rooms per person in previous dwelling.

Worse conditions in previous dwelling (room stress) should encourage to change from rental accomodation to own a house. 
Figure 5: Homeownership rate among nationals(n) and not-nationals(i) among households' breadwinners (source: CHER 2000)

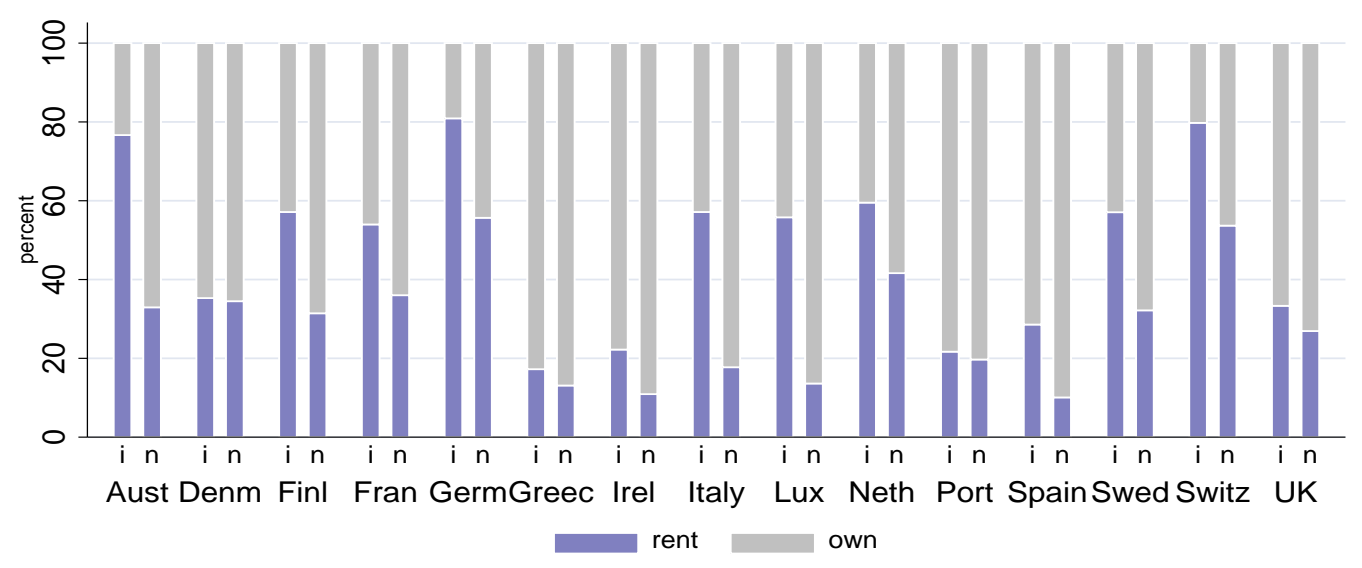

- dIncBurd - Difference between income burden in current and previous dwelling (rent to income or mortgage payment to income ratio).

The impact of the variable dIncBurd is not clear, as on one hand households seek to lower burden on their income, on the other might be ready to decide to increase the burden if only it will give them one day a possibility to own a dwelling.

Estimated parameters for each country will enable to state whether there are substantial differences in households behaviour across European countries. Coefficients in the logit model cannot be interpreted directly. One way is to compute partial derivatives of the probability that $y_{1}=1$ with respect to each explanatory variable. Signs of the marginal effects correspond to the signs of the coefficients, however the value of marginal effects depend upon the values of variables (Verbeek, 2004). It is quite common to compute marginal effects holding all variables at their mean. Another way is to interpret model coefficients in terms of changes in the odds. The odds of observing a positive outcome versus a negative one is equal to an exponential of the right side of the logit model:

$$
\Omega(x)=\frac{P(O W N=1 \mid x)}{1-P(O W N=1 \mid x)}=e^{\sum \beta_{k} x_{k}}=e^{\beta_{0}} e^{\beta_{1} x_{1}} e^{\beta_{2} x_{2}} \ldots e^{\beta_{k} x_{k}}
$$

A unit change in variable $x_{k}$ leads to change in the odds by a factor of $e^{\beta_{k}}$, holding all other variables constant.

$$
\frac{\Omega\left(x, x_{k}=a+1\right)}{\Omega\left(x, x_{k}=a\right)}=\frac{e^{\beta_{0}} e^{\beta_{1} x_{1}} \ldots e^{\beta_{k} a} e^{\beta_{k}}}{e^{\beta_{0}} e^{\beta_{1} x_{1}} \ldots e^{\beta_{k} a}}=e^{\beta_{k}}
$$

For $e^{\beta_{k}}>1$ the odds are ' $e^{\beta_{k}}$ times larger', for $e^{\beta_{k}}<1$ the odds are ' $e^{\beta_{k}}$ times smaller' 
Figure 6: Homeownership rates by country and urban/rural area (source: CHER 2000)

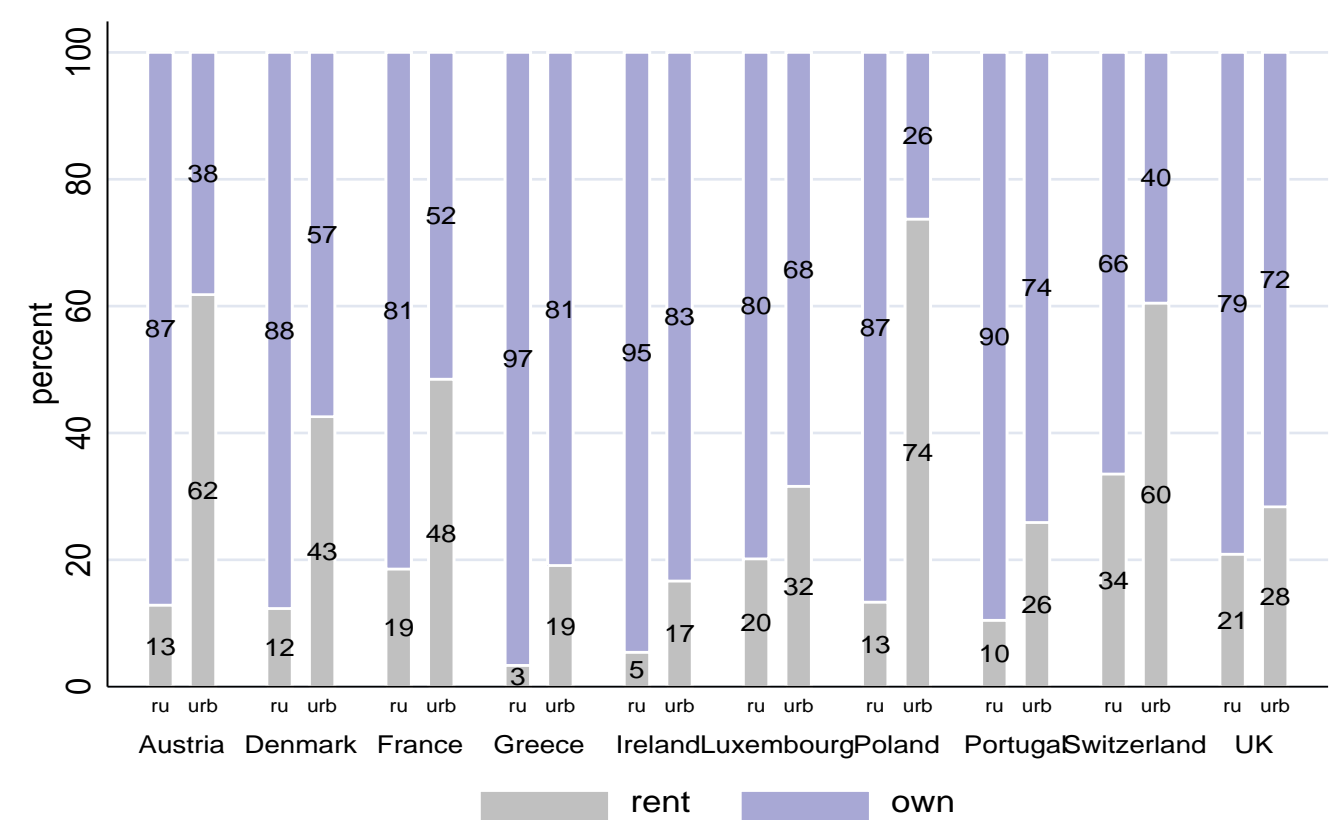

(Long and Freese, 2001). All model estimations presented in this paper were carried out with the use of SPSS software, which computes by default the exponentials of model coefficients. Therefore this paper uses the latter method of interpreting model results. All tables with model results instead of coefficients contain exponentials of the coefficients.

\section{Results}

\section{Model 1}

Estimated impact of variables on the odds of homeownership (exponents of model coefficients) are presented in table 1 and table 2 . Model 1 contains a short subset of variables so as to enable comparison of the largest number of countries. It shows that in most countries homeownership is increasing with age. This is quite intuitive as age can be treated as a proxy of accumlated wealth. In most countries the fact that a household is headed by an individual aged at least 30 increases the odds of homeownership. However, in Italy and Portugal there is no significant difference between households with the breadwinner aged 16-29 and 30-39. This might be explained by the fact that in Southern European countries it is common for young people, if they cannot afford a new home, to stay with their parents until late age (up to 30). Therefore there is little percentage of renters among young households in these countries compared to other European countries. In Netherlands the odds 
of homeownership at the age $60+$ are not significantly different from the odds of homeownership at the age 16-29. This means that old (perhaps retired) households in Netherlands sell their homes and become renters. It may be connected with the need to increase their consumption or simply with problems of 'dealing with the non-financial challenges of home ownership' (VanderHart, 1994).

Very unusual results were obtained for Poland. The fact of being in a group of households with the breadwinner aged 30-60+ actually lowers the odds of homeownership. This might be explained by the fact that Polish housing market went through a transition period in 90s. Most of the Polish rental market is neither private nor social. It is owned by cooperatives and employers which built these flats during socialist times and sold them to households, however still not giving them homeownership rights. In 90s privatization of public housing in Poland started but it seems that more young households have become homeowners than the older households. Such atypical structure of housing market makes it very difficult to analyse it. An example is research by Fisher and Jaffe (2003) who when comparing international homeownership rates simply excluced all 'transition' countries as atypical.

As expected marriage in each country is a significant incentive to buy a house. The odds of homeownership for married couples are from 1.2 to 3.2 times higher compared to single people and partnerships.

Nationality plays in many countries even more important role in explaining tenure choice than marriage. In Germany, Italy, Luxembourg, Austria or Spain people with national citizenship have from 4 to 7.9 times higher odds of being a homeowner.

Income as expected has a positive influence on the odds of owning a home. The exceptions are Greece, Portugal and Poland where income seems insignificant. One explanation is that in Southern European countries it is quite common for parents to help financially their children to buy their property, so income of the young households does not play a significant role in determining their tenure choice. (Earley, 2004). Another explanation is that this is a result of not controlling whether a household lives in urban or rural area. Incomes in rural area are much lower but homeownership rates are usually much higher there.

\section{Model 2}

Second model is a development of Model 1. Two new variables are included, however as a 
trade-off a limited number of countries are compared, as these variables were not available for all countries. Model 2 accounts for the type area a household is living in: urban or rural. It also distinguishes three household types: partnership, married versus single status (results are presented in Table 3). When controlling for urban/rural indicator income in Greece and Portugal becomes significant in explaining tenure choice. In case of Poland, although income shows a positive impact on the odds of homeownership it remains insignificant. This again may be explained by the fact that many of the households classified as renters are living in community owned flats, which they actually had to buy but did not receive ownership rights.

In all presented countries (except for UK) the odds of ownership is much lower in urban area.

In most of the countries cohabitating couples are more likely to rent a dwelling than a single person. Only in Denmark cohabitating status has significantly higher odds of homeownership compared to single people (however still twice lower compared to marriage). To some extent this might be explained by the popularity of cohabitating status in a given country. In Denmark there is one of the highest percentage of partnerships.

\section{Model 3}

Moodel 3 is a result of endogenous sample selection (results are presented in Table 4 and Table 5). Only homeowners and renters in private sector are included. Such sample selection leads to exclusion of many households with low income, high number of children and probably sinlge parents. This means that conditioning upon the outcome of the selection process has an effect on the conditional distribution of dependent variable $y_{i}$ (Verbeek, 2004).

$$
F(y \mid x, r=1) \neq F(y \mid x)
$$

Where $r$ is a dummy variable indicating selection, $r=1$ when a household is a homeowner or rents accomodation from private landlord, and $r=0$ when a household rents an accomodation from public landlord. Such selection bias allows to interpret model coefficients (e.g. their change in significance) with reference to coefficients obtained in the Model 1. First thing worth noting is that, when excluding from the sample public rental market it occurs that nationality in some countries plays even more significant role in defining tenure choice than it resulted from Model 1(in Germany and Austria the impact of nationality on the odds of homeownership rose twice, in Netherlands the coefficient gained significance). This indicates that households headed by individuals that are not nationals live mainly in private rental market and are not entitled to social rental housing. 
On the other hand in Finland the impact of nationality has lost significance compared to Model 1 which indicates that many not-national households are entitled to live in public rental accommodation.

\section{Model 4}

In Model 4 sample is confined only to recent movers (moved to current dwelling in 1995 or later). Recent movers should better reflect the relationship between household preferences, financial situation and their tenure choice (although it reduces the sample substantially; results are presented in Table 6).

Positive influence of IncBurd variable means that all households are ready to increase burden on their income in order to become a homeowner. The impact of income on the odds of homeownership in case of recent movers is much higher compared to models built on the whole sample of households. The so called room stress effect is only valid in case of Spain. The lower size of the housing (lower number of rooms per person) in previous dwelling the higher probability of turning to or remaining in ownership. In Germany, Netherlands and UK households aged 60 and more have significantly higher odds of being a tenant compared to young households.

\section{Summary}

This paper attempts to compare European countries in terms of microeconomic factors influencing housing tenure choice. Differences in homeownership rates among European countries arise mainly from different approaches of governments toward housing (supporting homeownership or social renting). However if these differences were eliminated and a common housing policy was adopted there still will be differences in homeownership rates. Estimations of logit models built for each country separately show that nationality plays a significant role in determining the homeownership status in Germany, Luxembourg or Austria, while in Denmark it doesn't. Marriage in all countries proved to be a significant incentive to buy a house. Cohabitating couples are more likely to rent a dwelling than a single person, however the exception is Denmark, where cohabitating status has significantly higher odds of homeownership compared to single people. In most countries the fact that a household is headed by an individual aged at least 30 increases the odds of homeownership. However, in Netherlands the odds of homeownership at the age $60+$ are not significantly different from the odds of homeownership at the age 16-29. This means that old (perhaps 
retired) households in Netherlands sell their homes and become renters. Unusual results for Poland might be explained by the fact its housing market went through a transition period. Most of the Polish rental market is neither private nor social. It is owned by cooperatives and employers which built these flats during socialist times and sold them to households, however still not giving them homeownership rights. Overall, results indicate that different numbers of not-national households living in particular countries, different levels of acceptance of partnership status, different average age of forming a new household will keep different structures of tenure choice across European countries, even if a common housing policy was adopted (supporting homeownership or renting). 


\section{References}

Andrew, M. (2004) A Permanent Change in the Route to Owner Occupation? Scottish Journal of Political Economy, Vol. 51, No. 1, February 2004

Andrew, M., Meen, G. (2003) Housing Transactions and the Changing Decisions of Young Households in Britain: The Microeconomic Evidence, Real Estate Economics, V31 1:pp. 117-138

Arimah, B.C. (1997) The Determinants of Housing Tenure Choice in Ibadan, Nigeria. Urban Studies Vol. 34, No. 1, 105-124.

Barcelo, C. (2006) Housing Tenure and Labour Mobility: A Comparison Across European Countries, Documentos de Trabajo No 0603, Banco de Espana, Madrid, 2006

Ben-Shahar, D. (2007) Tenure Choice in the Housing Market: Psychological Versus Economic Factors, Environment and Behavior 2007; 39; 841

Birch, A., Haag, A., Lefebure, S., Villeret, A. and Gunther Schmaus under support of Fisher, K., Frick, J. Kuchler, B. and Hegerle, N. (2003) - User guide, CHER Working paper 2, CEPS/INSTEAD, Differdange, G.-D. Luxembourg.

Bourassa, S.C. (2000) Ethnicity, Endogenity, and Housing Tenure Choice. Journal of Real Estate Finance and Economics, 20:3, 323-341.

Bourassa, S.C., Yin, M. (2006) Housing Tenure Choice in Australia and the United States: Impacts of Alternative Subsidy Policies, Real Estate Economics, V34 2: pp. 303328

Chen, J., Ost, C.E. (2005) Housing Allowance and the Recipients Homeownership: Evidence from a Panel Data Study in Sweden, Housing Studies, Vol. 20, No. 4, 605625, July 2005

Clark, W. A. V. , Deurloo, M. C., Dieleman F. M. (1997) Entry to Home-ownership in Germany: Some Comparisons with the United States, Urban Studies, Vol. 34, No. 1, 7-19,

Earley, F. (2004) What explains the differences in homeownership rates in Europe?, Housing Finance International, Sep 2004 
Fisher, L. M., Jaffe, A. J. (2003) Determinants of international home ownership rates, Housing Finance International, Sep 2003

Gabriel, S.A., Painter, G. (2008) Mobility, Residential Location and the American Dream: The Intrametropolitan Geography of Minority Homeownership. Real Estate Economics, V36 3: pp. 499531

Hennessey, S.M. (2001) The Impact of the Tenure Choice Decision on Future Household Wealth

Iwarere, L.J., Williams, J.E.(1991) A micro-Market Analysis of Tenure Choice Using The Logit Model. The Journal of Real Estate Research. Volume 6, Number 3 (Fall): $327-339$.

Long, J.S., Freese, J. (2001) Regression Models for Categorical Dependent Variables Using Stata. Stata Press Publication

Skaburskis, A. (1999) Modelling the Choice of Tenure and Building Type, Urban Studies, Vol. 36 No 13, 2199-2215, 1999

VanderHart, P. G. (1994) An Empirical Analysis of the Housing Decisions of Older Homeowners, Journal of the American Real Estate and Urban Economics Association 1994, V22, 2: pp. 205-233

Verbeek, M. (2004) A Guide to Modern Econometrics, John Wiley \& Sons 


\section{Appendix}

Numbers in all tables are exponentials of the estimates of the model coefficients $\operatorname{Exp}(\beta)$.

If $\operatorname{Exp}(\beta)>1$ then variable has a positive effect on the odds of homeownership $\frac{\operatorname{Prob}(\text { Own })}{\operatorname{Prob}(\operatorname{Rent})}$

If $\operatorname{Exp}(\beta)<1$ then variable has a negative effect on the odds of homeownership $\frac{\operatorname{Prob}(\text { Own })}{\text { Prob(Rent })}$

$* * *$ Denotes that the estimates of the model coefficient $\beta$ was significant at $1 \%$ level

** Denotes that the estimates of the model coefficient $\beta$ was significant at $5 \%$ level

* Denotes that the estimates of the model coefficient $\beta$ was significant at $10 \%$ level

Table 1: Model1(Germany, Italy, Luxembourg, The Netherlands, Switzerland, United Kingdom, Austria, Denmark). Dependent variable: 1 if own and 0 if rent.

\begin{tabular}{l|l|l|l|l|l|l|l|l}
\hline Variable & Germ & Ital & Lux & Neth & Switz & UK & Aust & Denm \\
\hline age30to40 & $1.8 * * *$ & 1.0 & $1.4 * *$ & $1.9 * * *$ & $1.5 * *$ & $2.0 * * *$ & 1.0 & $1.8^{* * *}$ \\
age40to60 & $2.6 * * *$ & $1.5 * * *$ & $2.7 * * *$ & $1.7 * * *$ & $4.2 * * *$ & $3.1 * * *$ & $1.3 *$ & $2.7 * * *$ \\
age60plus & $3.5 * * *$ & $1.9 * * *$ & $4.1 * * *$ & .9 & $6.6 * * *$ & $3.5 * * *$ & 1.2 & $2.7 * * *$ \\
married & $2.2 * * *$ & $1.2 * * *$ & $1.5^{* * *}$ & $2.2 * * *$ & $3.1 * * *$ & $2.3 * * *$ & $2.1 * * *$ & $3.2 * * *$ \\
national & $4.0 * * *$ & $9.7 * * *$ & $7.9 * * *$ & $2.1 * *$ & $3.1 * * *$ & $1.9 * *$ & $6.4 * * *$ & 1.3 \\
lninc & $2.5 * * *$ & $1.6 * * *$ & $2.6 * * *$ & $5.9 * * *$ & $2.3 * * *$ & $3.0 * * *$ & $1.4 * * *$ & $2.7 * * *$ \\
Constant & $.0 * * *$ & $.0 * * *$ & $.0 * * *$ & $.0 * * *$ & $.0 * * *$ & $.0 * * *$ & $.0 * * *$ & $.0 * * *$ \\
\hline -2LogLikelih & 7690.1 & 4966.3 & 2077.6 & 5221.5 & 4110.6 & 3835.4 & 2909.5 & 2371.1 \\
Nagelkerke R2 & .23 & .04 & .36 & .34 & .29 & .26 & .10 & .30 \\
$\mathrm{~N}$ & 6579 & 5448 & 2314 & 4905 & 3672 & 3981 & 2407 & 2251 \\
\hline
\end{tabular}

Table 2: Model1 (Finland, France, Greece, Ireland, Portugal, Spain, Poland). Dependent variable: 1 if own and 0 if rent.

\begin{tabular}{l|l|l|l|l|l|l|l}
\hline Variable & Finl & Fran & Gree & Irel & Port & Spain & Pol \\
\hline age30to40 & $2.9 * * *$ & $3.7^{* * *}$ & $1.7 * * *$ & $1.5 *$ & 1.2 & $1.4 * *$ & $.6 * *$ \\
age40to60 & $6.2^{* * *}$ & $7.8^{* * *}$ & $3.0 * * *$ & $4.1 * * *$ & $1.3 * *$ & $2.0 * * *$ & $.6 * * *$ \\
age60plus & $23.9 * * *$ & $16.3 * * *$ & $7.3^{* * *}$ & $21.0 * * *$ & $1.4 * * *$ & $2.9 * * *$ & $.7 * *$ \\
married & $1.8 * * *$ & $2.5 * * *$ & $1.4 * * *$ & $1.9 * * *$ & $1.4 * * *$ & $1.8 * * *$ & $1.4 * * *$ \\
national & $2.8^{*}$ & $2.7 * * *$ & 2.0 & $3.2 *$ & 1.4 & $4.2 * * *$ & \\
lninc & $4.3 * * *$ & $2.0 * * *$ & 1.0 & $3.0 * * *$ & 1.1 & $1.3 * * *$ & .9 \\
Constant & $.0 * * *$ & $.0 * * *$ & .5 & $.0 * * *$ & .7 & $.0 * * *$ & $3.5 * *$ \\
\hline -2LogLikelih & 2556.7 & 5284.5 & 2621.0 & 1056.3 & 3952.2 & 3003.8 & 4041.1 \\
Nagelkerke R2 & .47 & .32 & .09 & .24 & .01 & .06 & .01 \\
N & 3039 & 5034 & 3593 & 1868 & 3989 & 4763 & 2751 \\
\hline
\end{tabular}


Table 3: Model2 (Switzerland, United Kingdom, Austria, Denmark, France, Greece, Ireland, Portugal, Poland). Controlling for urban/rural area and partnership status. Dependent variable: 1 if own and 0 if rent.

\begin{tabular}{|c|c|c|c|c|c|c|c|c|c|}
\hline Variable & Swit & UK & Aust & Den & Fran & Greec & Irel & Port & Pol \\
\hline age 30 to 40 & $1.5 * *$ & $2.0 * * *$ & 1.3 & $1.8 * * *$ & $4.0 * * *$ & $1.7 * * *$ & $1.5 *$ & $1.4 * *$ & .9 \\
\hline age 40 to60 & $4.4^{* * *}$ & $3.2 * * *$ & $1.8^{* * *}$ & $3.1 * * *$ & $8.9 * * *$ & $3.0 * * *$ & $4.0 * * *$ & $1.4^{* *}$ & .9 \\
\hline age60plus & $7.5 * * *$ & $3.6^{* * *}$ & $2.2 * * *$ & $2.8 * * *$ & $18.6^{* * *}$ & $6.8^{* * *}$ & $18.2 * * *$ & $1.4^{* *}$ & 1.1 \\
\hline married1 & $2.5 * * *$ & $2.4^{* * *}$ & $1.6 * * *$ & $3.8^{* * *}$ & $1.8^{* * *}$ & $1.3 *$ & $1.8 * * *$ & $1.3^{* * *}$ & \\
\hline cohab & $.4^{* * *}$ & 1.0 & $.6 * *$ & $1.6 * * *$ & $.7 * * *$ & 1.2 & .7 & $.5 * * *$ & \\
\hline national & $2.8 * * *$ & $1.8 *$ & $7.2 * * *$ & 1.4 & $1.9 * * *$ & 2.0 & $3.6^{* *}$ & 1.2 & \\
\hline $\operatorname{lninc}$ & $2.7^{* * *}$ & $2.9 * * *$ & $1.6 * * *$ & $2.2^{* * *}$ & $2.6^{* * *}$ & $1.1 *$ & $3.1 * * *$ & $1.3 * * *$ & 1.1 \\
\hline urban & $.3 * * *$ & .9 & $.1^{* * *}$ & $.2 * * *$ & $.2 * * *$ & $.2 * * *$ & $.3^{* * *}$ & $.3^{* * *}$ & $.1 * * *$ \\
\hline Constant & $.0 * * *$ & $.0 * * *$ & $.0 * * *$ & $.0 * * *$ & $.0 * * *$ & .5 & $.0 * * *$ & $.2^{* *}$ & 2.5 \\
\hline -2LogLikelih & 3937.2 & 3338.3 & 2274.8 & 2215.0 & 4704.8 & 2420.3 & 997.9 & 3440.7 & 2896.9 \\
\hline Nagelkerke R2 & .33 & .27 & .39 & .36 & .40 & .17 & .29 & .09 & .44 \\
\hline $\mathrm{N}$ & 3667 & 3457 & 2398 & 2236 & 4894 & 3585 & 1865 & 3754 & 798 \\
\hline
\end{tabular}


Table 4: Model3 (Germany,Italy, Luxembourg, The Netherlands, UK, Austria,Denmark). Dependent variable: 1 if own and 0 if rent privately.

\begin{tabular}{l|l|l|l|l|l|l|l}
\hline Variable & Germn & Italy & Lux & Neth & UK & Aust & Denm \\
\hline age30to40 & .9 & .9 & $2.5 * *$ & $3.5 * * *$ & $3.0 * * *$ & 1.0 & $2.2 * * *$ \\
age40to60 & $1.6 * * *$ & $1.6 * * *$ & $2.6^{* * *}$ & $5.2 * * *$ & $4.6 * * *$ & $1.6 * *$ & $4.5 * * *$ \\
age60plus & $2.3^{* * *}$ & $2.3^{* * *}$ & $4.3^{* * *}$ & $3.4 * * *$ & $6.9 * * *$ & $1.4 *$ & $5.9 * * *$ \\
married & $1.2 * *$ & $1.2 * *$ & 1.3 & $8.0 * * *$ & $3.1 * * *$ & $2.7 * * *$ & $3.8 * * *$ \\
national & $8.6 * * *$ & $8.6 * * *$ & $2.6^{* * *}$ & 2.6 & $3.1 * * *$ & $13.9 * * *$ & 1.3 \\
lninc & $1.5 * * *$ & $1.5 * * *$ & $6.6 * * *$ & $2.8 * * *$ & $2.4 * * *$ & $1.4 * * *$ & $2.4 * * *$ \\
Constant & $.0 * * *$ & $.0 * * *$ & $.0 * * *$ & $.0 * * *$ & $.0 * * *$ & $.0 * * *$ & $.0 * * *$ \\
\hline-2 LogLikelih & 5933.2 & 3786.4 & 417.5 & 1115.5 & 2129.8 & 1738.0 & 1405.9 \\
Nagelkerke R2 & .249 & .049 & .187 & .357 & .266 & .145 & .322 \\
$\mathrm{~N}$ & 5056 & 5134 & 1722 & 3086 & 3363 & 1966 & 1818 \\
\hline
\end{tabular}

Table 5: Model3 (Finland, France, Greece, Ireland, Spain, Poland). Dependent variable: 1 if own and 0 if rent privately.

\begin{tabular}{l|l|l|l|l|l|l}
\hline Variable & Finl & Fran & Gree & Irel & Spain & Pol \\
\hline age30to40 & $3.5 * * *$ & $4.5 * * *$ & $1.5 * *$ & $1.5^{*}$ & $1.3 *$ & .8 \\
age40to60 & $9.6 * * *$ & $11.3 * * *$ & $2.7 * * *$ & $10.2 * * *$ & $2.2 * * *$ & 2.1 \\
age60plus & $42.5 * * *$ & $23.3 * * *$ & $6.2 * * *$ & $29.2 * * *$ & $2.9 * * *$ & $9.7 * * *$ \\
married & $1.8 * * *$ & $2.5 * * *$ & $1.4 * * *$ & $5.9 * * *$ & $2.0 * * *$ & 1.7 \\
national & .0 & $1.8 * *$ & $2.2 *$ & 2.5 & $4.6 * * *$ & \\
lninc & $4.8 * * *$ & $1.7 * * *$ & .9 & $2.1 * * *$ & $1.3 * * *$ & $1.3 *$ \\
Constant & 2.1 & $.0 * * *$ & 2.8 & $.0 * * *$ & $.0 * * *$ & 1.0 \\
\hline -2LogLikelih & 1408.8 & 3553.7 & 2519.2 & 420.4 & 2619.7 & 386.6 \\
Nagelkerke R2 & .513 & .346 & .087 & .291 & .069 & .066 \\
N & 2530 & 4209 & 3564 & 1729 & 4683 & 1491 \\
\hline
\end{tabular}


Table 6: Model4 (Germany, The Netherlands, UK, Denmark, Finland, France, Spain). Dependent variable: 1 if own and 0 if rent. Sample confined only to recent movers (moved to current dwelling in 1995 or later)

\begin{tabular}{l|l|l|l|l|l|l|l}
\hline Variable & Germany & Neth & UK & Denm & Finl & Fran & Spain \\
\hline dIncBurd & $15.3^{* * *}$ & $34.4 * * *$ & 1.0 & 1.3 & 1.5 & $6.4 * * *$ & $9.7^{* * *}$ \\
h00d14 & $1.1 *$ & 1.1 & 1.0 & 1.0 & 1.0 & $.9 *$ & 1.1 \\
lninc & $7.3^{* * *}$ & $9.0 * * *$ & $6.3 * * *$ & $10.4 * * *$ & $7.0 * * *$ & $4.2 * * *$ & $1.7 * * *$ \\
PrevRoomsPerPers & $1.2^{*}$ & 1.1 & $1.5 * * *$ & 1.2 & $1.3 *$ & .9 & $.7 *$ \\
age30to40 & 1.4 & 1.5 & $1.9 * * *$ & 1.3 & $1.9 * * *$ & $3.4 * * *$ & 1.5 \\
age40to60 & 1.5 & 1.2 & $1.6 * * *$ & 1.0 & 1.3 & $3.8^{* * *}$ & .9 \\
age60plus & $.5 * *$ & $.1 * * *$ & $.3 * * *$ & .6 & 1.8 & 1.4 & .5 \\
married & $3.2 * * *$ & $3.1 * * *$ & $3.3 * * *$ & $1.8 * *$ & $1.7 * *$ & $2.1 * * *$ & $1.8^{*}$ \\
national & $3.4 * * *$ & 3.6 & 1.7 & 1.9 & 1.7 & .9 & $5.5 * *$ \\
Constant & $.0 * * *$ & $.0 * * *$ & $.0 * * *$ & $.0 * * *$ & $.0 * * *$ & $.0 * * *$ & $.0 * * *$ \\
\hline -2LogLikelih & 1267.8 & 720.6 & 1547.2 & 677.3 & 694.3 & 1167.9 & 340.6 \\
Nagelkerke R2 & .391 & .530 & .467 & .413 & .371 & .317 & .216 \\
$\mathrm{~N}$ & 1541 & 841 & 1902 & 668 & 693 & 1083 & 319 \\
\hline
\end{tabular}

